\title{
Effects of phosphorus on yield of cowpea cultivars intercropped with pearl millet on Psammentic paleustalf in Niger ${ }^{1}$
}

\author{
B R Ntare \& A Batıono* \\ ICRISAT Sahelian (enter BP 124(4) NiameI Niger
}

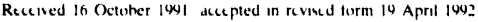

Ke's nords Vigna unguiculata $P$ response Pennisetum glacum Sahel

\begin{abstract}
Phosphorus (P) is the most limiting soil nutrent in the sandy sols of Niger and farmers rarely use chemical tertilizers in producing pearl millet and cowped A 3-yr study was conducted in farmer s fields at two locations in South Western Niger to investigatc yield rcuponse of six cowped cultivars to applied P fertilizer ( $(0) 816 \mathrm{kgha}$ ') when intercropped with millu Significant yicld differences were found between cultivars for their seed and dry fodder yicld at all ratcs of applied $P$ ( ultivars responded differently to the application of $P$ Millet gran was more than doubled with the addition of 8 to $16 \mathrm{kgPha}{ }^{\prime}$ Cowped cultivars did not have significant differential eflect on millet yiclds Cowped cultivars differed significantly in the decumulation of $P$ in fodder with the highest yiclding cultivars taking up more $P$ than the low yiclding ones The rcsults have important implications for breeding and selection of cowpea cultuvars that arc adapted to a range of fertility levels
\end{abstract}

\section{Introduction}

Intcrcropping pcarl millet (Pennisetum glaucum (L) $\mathrm{R} \mathrm{Br}$ ) and cowped (Vigna unguiculata (L) Walp ) is a common practice in Niger and other Sahelian countries of West Atrica [3] Millet and cowped are grown under lımited moisture condı toons and consequently farmers traditionally use low densities of both crops to reduce the risk of yield loss due to moisture stress The soils arc low in soll fertility and $P$ is the most limiting of all nutrients [1] but farmers rarely use chemxal fertilizers becduse of their relatively high cost

The yield of cowped as d sole crop can be improved with different indigenous sources of $P$ in Niger [2] Work conducted in the Sudanian zone of Burkına Faso indicated that response to $P$ depended on cowpea plant type [5]

A number of improved cowped cultivars of

- Submitted as Journal Article No 1211 of IC RISAT difterent plant types have been developed $[8]$ These yicld very well in monoculture with high inputs of fertilizers and pesticides There is incredsing interest in breeding cowped that is suitable for intercropping with pearl millct Understanding of cowped cultivar response to added $P$ in intereropping may contributc to the selection of such cultivars The objective of the study was to determine the yield response to $P$ of six cowped cultivars intercropped with millet and to examine the implications for breeding cowped cultivars adapted to a range of fertility cond tions

\section{Materials and methods}

The study was conducted in 1987, 1988 and 198s in a farmer s ficld at Sadore, near the ICRISAT Sahelıan Center (ISC) $43 \mathrm{~km}$ south of Niamey. 
and at Goberi, $120 \mathrm{~km}$ east of Niamey in Niger. The soils at the two sites are derived from colian sand deposits (Siliceous, isohyperthermic Psammentic palcustalf) and are representative of soils presently used for millet/cowpea production in the Sahel. The initial soil status at Sadore was: $\mathrm{pH}(\mathrm{KCl} 1: 1) \quad 3.0 ; 0.40 \%$ organic matter; 3.60) ppm Bray $1 \mathrm{P}$; and $96 \%$ sand. At Goberi, $\mathrm{pH}$, organic matter, Bray I P, and sand were $4.20,0.37 \%, 3.30 \mathrm{ppm}$, and $96 \%$, respectively. The field at Goberi had been under bush fallow for more than 5 years while at Sadore the field had millet in the preceding year.

The treatments were arranged in a randomized split-plot design with four replications. The $P$ rates ( 0,8 , and $\left.16 \mathrm{~kg} \mathrm{ha}{ }^{\prime}\right)$ were the main plots and six cowpea cultivars as subplots. The cowpea cultivars were: TVX 4659-(1)3E, an erect indeterminate cultivar. TN88-63, a commercial cultivar in Niger, Dan Illa and TN5-78, recently released local cultivars in Niger; and two local land races: Sadore Local grown mainly for fodder and Tera Local grown for grain and fodder. Except for Sadore Local which is photosensitive and late maturing ( $>9()$ days from sowing), all the others are photoinsensitive and mature in 75 days after sowing. In all the trials a 110 day millet cultivar, CIVT, the most common improved variety in Niger, was used.

In 1987 and 1988. single superphosphate was broadeast on the soil surface before sowing and mixed in the upper $5 \mathrm{~cm}$ of the soil at the first weeding of millet (10 days after sowing) using a local hoe. Trials were carried out on the same plots in both years. In 1989, no fertilizer was added to determine the residual effect of $P$. Millet plots were planted in 5 rows of $6 \mathrm{~m}$ long with an inter- and intra-row spacing of $1.50 \mathrm{~m}$ and $0.75 \mathrm{~m}$, respectively. Four rows of cowpea were intersown between the millet rows with a similar spatial arrangement as for the millet. Sowing of cowpea ranged from 2 to 6 weeks after millet. Each crop was thinned to three plants per hill. Nitrogen $\left(45 \mathrm{~kg} \mathrm{ha}{ }^{-1}\right)$ as urea was applied to millet in two equal amounts, half at 23 days after sowing (DAS) and half at 45 DAS. In 1987 cowpea was not sprayed with insecticide to control pests following farmer's practice and this resulted in no grain production.In the following years cowpea was sprayed with Cymbush ${ }^{(R)}$ twice during cropping to control flower and post flowering insects.

Rainfall at Sadore in 1987 was $450 \mathrm{~mm}, 20 \%$ below the long term average $(560 \mathrm{~mm})$ for Niamey. Sufficient rainfall for sowing was delayed until July 15 . In 1988 rainfall was $699 \mathrm{~mm}$, well-distributed with all the months of July to September recording above average rainfall. In 1989 . June rainfall was poorly distributed and $41 \%$ below the long term average. In July it was $36 \%$ below average. There was a dry spell of 20 days during July and moisture stress was evident. At Gobcri, rainfall was $4103 \mathrm{~mm}$ in $1987.650 \mathrm{~mm}$ in 1988 and $426 \mathrm{~mm}$ in 1989 . The distribution showed similar trends as at Sadore.

\section{Results}

Cowpea yields:. In 1987, significant yield differences were found between cultivars in their dry fodder yield at all $P$ rates (Table 1). The interaction cultivar-by $P$ rate was also significant $(P<$ 0.05). Sadore Local produced significantly more dry fodder at both rates of $P$ than the other cultivars. However, the yield of Sadore Local was reduced at the higher $P$ rates. The other cultivars produced low yields but responded more to added $P$.

In $1988 \mathrm{P}$ rates and cultivar effects were significant $(P<0.01)$ for grain and dry fodder at both sites (Table 2), but there were significant cultivar-hy-P level interactions. The higher $P$ rate significantly increased yields combined over cultivars. The grain yield of Sadore Local was low at Sadore due to poor insect pest control but it produced the highest average grain yield at Goberi where insect control was better.

In 1989 yields were extremely low (Table 3). Nonetheless, residual $P$ had a significant $(P<$ $0.05)$ effect on grain and dry fodder yields that were somewhat higher at the P rate $16 \mathrm{~kg} \mathrm{ha}^{-1}$. Sadore Local was again the highest yielder at the two sites. At Sadore the cultivars exhibited an average $100 \%$ increase in seed yield and at Goheri $223 \%$. For dry fodder the increase was $47 \%$ at Sadore and $100 \%$ at Goberi. Individual cultivars showed different yield responses to the application of $\mathbf{P}$ and the increases were markedly higher in 1989 than in the preceding year. 
Table 1. Dry fodder yield (kg ha ') of six cowpea cultivars as affected by the application of P-fertilizer in 1987

\begin{tabular}{|c|c|c|c|c|c|c|c|c|}
\hline \multirow[t]{3}{*}{ Cowpea cultivars } & \multicolumn{8}{|c|}{$\mathrm{P}$ rate $\mathrm{kg}$ ha } \\
\hline & \multicolumn{4}{|c|}{ Sadore } & \multicolumn{4}{|c|}{ Cinberi } \\
\hline & 0 & 8 & 16 & Mean & 1) & 8 & in & Méan \\
\hline Tvx 4659-()3E & 65 & $\varphi_{1}$ & 120 & 90 & 120 & 95 & 1.30 & 115 \\
\hline TN88.63 & 45 & 110 & $I(x)$ & 85 & $30)$ & 70 & 80 & (N) \\
\hline Tera Local & $160 \mid$ & 135 & $\mid(M)$ & $16(6)$ & 110 & 150 & 170 & 140 \\
\hline Sadore Local & 370 & +30 & 2.35 & 34.5 & (ot) & 470 & $4(x)$ & 520 \\
\hline Dan Illa & 50 & (⿻) & 165 & 40 & $1,30)$ & 45 & 120 & 115 \\
\hline TN5-78 & 220 & 150 & 210 & 195 & 2115 & 2001 & $2(t)$ & 240 \\
\hline Mean & 1.50 & $1(x)$ & 170 & 1601 & 210 & $|x|$ & 200 & $2(x)$ \\
\hline \multicolumn{9}{|l|}{ SE } \\
\hline Prates( $(P)$ & & & 5.6 & & & & 20.3 & \\
\hline Cultivars(C) & & & 13,3 & & & & 18.5 & \\
\hline $\mathrm{P} \times \mathrm{C}$ & & & 23.0 & & & & 31.4 & \\
\hline
\end{tabular}

Millet yield:. Millet grain yield response to $\mathrm{P}$ was highly significant $(P<0.01)$ in the three years and yields were more than doubled with the addition of $P$ (data not shown). Cowpea cultivar did not have significant differential effect on millet grain yicld.
$P$ uptake:. Cowpea cultivars differed significantly in the accumulation of $P$ in the fodder with the highest yiclding cultivar (Sadore Local) taking up morc $P$ than the other cultivars (Table 4). $P$ uptake was significantly affected by $P$ rate with a tendency for higher $P$ at $16 \mathrm{~kg}$ ha

Tahle 2. Effect of $\mathrm{P}$ rates on gram and fodder yield ( $\mathrm{kg}$ ha ${ }^{2}$ ) of six cowpea cultivars at two sites in lokx

\begin{tabular}{|c|c|c|c|c|c|c|c|c|}
\hline \multirow[t]{3}{*}{ Cowpea cultivars } & \multicolumn{8}{|c|}{ Prate kg ha } \\
\hline & \multicolumn{4}{|c|}{ Sadore } & \multicolumn{4}{|c|}{ Cinberi } \\
\hline & 0 & $x$ & 16 & Mean & 0 & $x$ & 16 & Mean \\
\hline \multicolumn{9}{|l|}{ Grain } \\
\hline$T v x+6599.013 \mathrm{E}$ & 70 & $I(x)$ & 1111 & $y 0$ & 120 & 1.31 & 240 & 16.5 \\
\hline Sadorc Local & 20 & 20 & 20 & 20 & 310 & 411 & $4 \times()$ & $4(x)$ \\
\hline TN\&K.6.3 & 115 & $2(k)$ & 2115 & 170 & $2601)$ & 241 & 310 & 270 \\
\hline Tera Local & 91 & 130 & 1,30 & 120 & 120 & $3(10)$ & 350 & $2(6)$ \\
\hline Dan Illa & 120 & 120 & 1.50 & 1,30 & 150 & $|6|$ & 250 & 190 \\
\hline TN5.7K & 150 & $|t| x \mid$ & $2(x)$ & 170 & $2(x)$ & 215 & 470 & 300 \\
\hline Mean & 9,5 & 121 & 140 & & $1 \times 5$ & 240 & 330 & \\
\hline \multicolumn{9}{|l|}{$\mathrm{Se}$} \\
\hline$P$ rate $(P)$ & & 5.3 & & & & 26.6 & & \\
\hline Cultivars (C) & & 8.4 & & & & 21.5 & & \\
\hline $\mathbf{P} \times \mathbf{C}$ & & 15.5 & & & & 37.2 & & \\
\hline \multicolumn{9}{|l|}{ Fodder } \\
\hline Tvx 4659-(),3E & $160)$ & 230 & $29(1)$ & 230 & 291 & 420 & 715 & $4 \times 0$ \\
\hline Sadore Local & 575 & 485 & $x 601$ & 640 & 635 & 920 & 1665 & 870 \\
\hline TN88.63 & 110 & 210. & $3(x)$ & 210 & 3211 & 270 & 310 & $3(x)$ \\
\hline Tera Local & 220 & $20(x)$ & 320 & 250 & $27(1)$ & 510 & 670 & 450 \\
\hline Dan Illa & 130 & 140 & $2(x)$ & $1(x)$ & 170 & $181)$ & $2(x)$ & 205 \\
\hline TN5.78 & 180 & 170 & 310 & 220 & 220 & 3.30 & 6.30 & 295 \\
\hline Mean & 210 & 225 & 355 & & 295 & 415 & 0.30 & \\
\hline \multicolumn{9}{|l|}{ SE } \\
\hline$P$ rates $(P)$ & & 22.7 & & & & 48.7 & & \\
\hline Cultivars (C) & & 30.2 & & & & 34.9 & & \\
\hline $\mathrm{P} \times \mathrm{C}$ & & 52.3 & & & & 6.05 & & \\
\hline
\end{tabular}


Tahle 3. Grain and dry fodder yield ( $\mathrm{kg}$ ha ') of s1x cowpea cultivars at two sites as influenced by residual $P$ in 1989

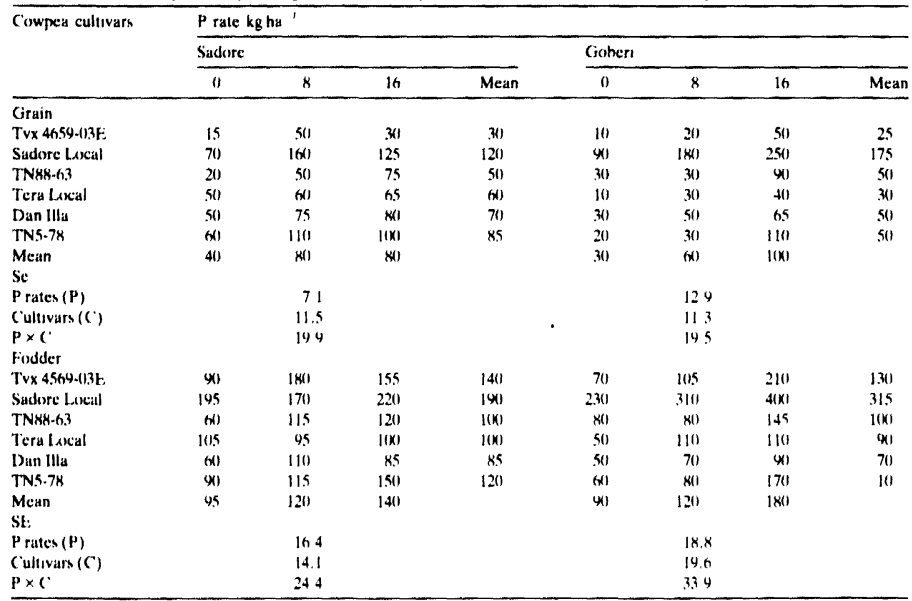

Tahle 4. P uptake (kg ha ') in cowpea fodder at three P tates

\begin{tabular}{|c|c|c|c|}
\hline Treutnent & Sadore 1487 & Ciotheri 1987 & Goberi 1988 \\
\hline \multicolumn{4}{|l|}{$P$ rate } \\
\hline 0 & 0.34 & . $\quad 045$ & 1) 38 \\
\hline 18 & 0.45 & 0.46 & 0.43 \\
\hline $3 n$ & 0.47 & 0.52 & 0,87 \\
\hline SE & (1).(144) & () (15) & $(1)+(x)$ \\
\hline \multicolumn{4}{|c|}{ Cowpea Cultivars } \\
\hline$T v x 4659-1) 3 \mathrm{~L}$ & 0.25 & 0.30 & 0.30 \\
\hline TN8R-6.3 & 0.22 & 0.15 & 0.30 \\
\hline Tera Local & 0.42 & 0.33 & (1) 77 \\
\hline Sadore Local & 0.8 .3 & 1.23 & $0.4 \%$ \\
\hline Dan Illa & 0.27 & 0.28 & 0.38 \\
\hline TN5-78 & 0.52 & 0.55 & 0.36 \\
\hline SE & 0,037 & 0.056 & 0.086 \\
\hline
\end{tabular}

\section{Discussion}

Interaction between cultivars and $P$ rates was observed with some cultivars declining in yield at higher $\mathrm{P}$ rates. This decline may have been due to millet competition. Better growth of the pearl millet (the dominant component) could have suppressed the cowpea. Some cultivars did not respond to $\mathrm{P}$ rate. $\mathrm{A}$ similar phenomenon was observed where fertilizer application significantly increased millet yields but had no effect on associated cowpea dry fodder [4]. Sadore Local, 
a photosensitive and a forage type cultivar produced the highest grain and fodder yield at all $P$ rates. This superiority may partly be due to its long growth duration or its spreading and indeterminate growth habit.

The detection of cultivar differences in yield at no $P$ application was encouraging in the context of breeding cultivars providing greater agronomic efficiency through reduced fertilizer costs. The differences in response to $\mathrm{P}$ could also have important implications for breeding and selection of cowpea cultivars adapted to a range of fertility conditions. Higher yield potential could itself lead to greater response to $P$ and greater efficiency in terms of yield/unit of applied $P$ at all levels. Further experimentation using a larger number of cultivars than in the present study should be worthwhile.

The erratic distribution of rainfall in 1987 and 1989 influenced the sowing of cowpea relative to that of millet. It has been shown that the planting date of intercrop cowpea relative to that of millet is critical with cowpea sown three weeks after millet giving extremely low yields [7]. When cowpea is sown in an already well-established millet stand the dominating effect of millet through shading and competition for nutrients may result in poor cowpea yields. Despite the low yields recorded in 1989, which was characterized by a pronounced dry spell, the percentage yield increase with the application of $P$ was markedly higher than the preceding year which had a favourable rainfall distribution. The reason for this is not clear. However, it is possible that yield response to higher $P$ rates is greatest under moisture stress conditions whereby plants in fertilized plots may have a much deeper root system that exploits moisture deeper in the profile than in non fertilized plots. This is an area that needs intensive study.

The results of this study show that grain and fodder yields of cowpea can be substantially increased by the application of phosphorus fertilizer and that cultivar differences in their response to applied $P$ could have important impli- cations in the breeding and selection of cowpea cultivars adapted to different fertility conditions.

\section{References}

1. Bationo A. Christianson (B \& Mokwunye. UA (1984) Soil fertility Management of millet producing sandy soils of Sahelian West Africa: The Niger Experience. pp 159168. In: Soil, Crop and Water Management Sysiems for Rainfed Agriculture in the Sudano-Saheliun zone: Proceedings of an International workshop, 11-16 Jan 1987. ICRISA'T Suhelian Center. Niamey, Niger. Patancheru, A.P. 5123234, India. Intcrnational Crops Research Institute for the Scmi-Arid Tropics

2. Bationo A, Ndunguru BJ, Ntare BR. ('hristianson BC \& Mokwunye UA (1990) Fertilizer munagement strategies for legume-hased cropping systems in the West African Semi-arid Tropics pp 213-226. In: Phosphorus nutrient of grain legumes in the seni-arid Tropics. Procedings of an Internutional Workshops k-11 Jan 1991) ICRISAT, Patancheru, A.P. 502.324, India. International Crops Research Institute for the Ssmi-Arid Tropics

3. Fussell I.K \& Scralini PG (1965) Associations des cultures dans les zones tropicales Semi-arides d'Afrique de I'Ouest: Strategies de recherches antérieures et futures. (In Fr.) pp 254-27X in: Téchnologies appropriées pour les paysans de zones semi-arides de l'Afrique de l'Ouest (Ohm W and Nagy S.G eds) West Lafingette Indiana. USA: Purdue University

4. IC'RISAT (International Crops Research Institute for the Semi-arid Tropics) (1986). Annual for Report 1985. Patancheru, India. ICRISAT.

5. IITA (International Institute of Tropical Agriculture). (1980). Annual Report for 1979. Ibadan, Nigeria

6. Ntare BR. Seratini PG \& Fussell LK (1989) Recent developments in Pear Millet/Cowpea cropping systems for low rainfall areas of Sudano-sahelian zone of West Africa. pp 277-2k9. in: Soil Crop, and Water Management systems for rainfed agriculture in Sudano-Sahelian zone: Proceedings of an International workshop 6-11 Jan 1989. ICRISAT Sahelain Center, Niamey, Niger. Patancheru. A.P. 502.324, India: International Crops Research Institute for the Semi-Arid Tropics

7. Ntare BR (199()) Intercropping Morphologically different Cowpeas with Pearl millet in a Short Seasin Environment of the Sahel Experimental Agriculture 26: (1): 41-47

8. Singh BB \& Ntarc BR (1985) Developmenl of improved cowpea varieties in Africa. pp 105-115. In: Cowpea Research Production and Utilization (S.R. Singh and K.O. Rachie eds). John Wiley \& Sons Chichester. New York 46() $\mathrm{pp}$ 
Table 3. Grain and dry fodder yield ( $\mathrm{kg}_{\mathrm{g}}$ ha ') of six cowpea cultivars at two sites as influenced by residual $\mathbf{P}$ in 1989

\begin{tabular}{|c|c|c|c|c|c|c|c|c|}
\hline \multirow[t]{3}{*}{ Cowpea cultivars } & \multicolumn{8}{|c|}{$P_{\text {rate }} \mathrm{kg}$ ha } \\
\hline & \multicolumn{4}{|c|}{ Sadure } & \multicolumn{4}{|c|}{ Goberi } \\
\hline & () & 8 & in & Mean & 0 & 8 & 16 & Mean \\
\hline \multicolumn{9}{|l|}{ Grain } \\
\hline Tvx 4659-(J3F. & 1.5 & 50 & $30)$ & 3) & 10 & 20) & 50 & 25 \\
\hline Sadore Local & 71) & $|60|$ & 125 & 120 & (Y) & $|8|$ & 250 & 175 \\
\hline TN\&K-6.3 & 211 & 50 & 75 & 50 & 30) & 30 & $x_{0}$ & 50 \\
\hline Tera Local & 50 & 601 & 65 & (n) & 10 & 31 & 411 & 30) \\
\hline Dan Illa & S1 & 75 & (2) & 70 & $3)$ & 50 & 65 & 50 \\
\hline TN5.7א & $(x)$ & 110 & $l(x)$ & 85 & 20 & 301 & 110 & 50) \\
\hline Mean & 411 & 81 & 80 & & 30 & (x) & $1(x)$ & \\
\hline \multicolumn{9}{|l|}{ Sc: } \\
\hline P rates ( $P$ ) & & 7.1 & & & & 12.9 & & \\
\hline Cultivars (C) & & 11.5 & & & & 11.3 & & \\
\hline $\mathrm{P} \times \mathrm{C}$ & & 14.9 & & & & 14.5 & & \\
\hline \multicolumn{9}{|l|}{ Fodver } \\
\hline Tvx 4564-113k: & $9(1$ & $|x|$ & 15.5 & 140 & 70 & 1115 & 210 & 130 \\
\hline Sadore Local & 145 & 170 & 220 & 101 & 2311 & .311 & $4(x)$ & 315 \\
\hline INKK-6.3 & $(x)$ & 115 & 120 & $1(x)$ & K(I) & 801 & 145 & $I(n)$ \\
\hline Tera Local & 105 & 95 & $1(x)$ & $\mid(x)$ & 50 & 110 & 110 & 9) \\
\hline Dan Illa & $(x)$ & 110 & $\times 5$ & 85 & 50 & 70 & 901 & 70 \\
\hline TN5.78 & (x) & 115 & 150 & 120 & (x) & $k(1$ & 1711 & 10 \\
\hline Mcan & 45 & 1211 & 141) & & (x) & 120 & 180 & \\
\hline \multicolumn{9}{|l|}{ St: } \\
\hline$P$ rates $(P)$ & & 16.4 & & & & 18.8 & & \\
\hline Cultivars (C) & & 14.1 & & & & 19.6 & & \\
\hline $\mathrm{P} \times \mathrm{C}$ & & 24.4 & & & & 3.3 .9 & & \\
\hline
\end{tabular}

Table 4. P uptake ( $k g$ ha ') in cowpea fodder at three $P$ rates

Treatment

Prate

\begin{tabular}{|c|c|c|c|}
\hline 0 & 0.34 & \multirow{2}{*}{$\begin{array}{l}4.5 \\
46\end{array}$} & 0.38 \\
\hline 18 & 0.45 & & 0.43 \\
\hline 36 & (1). 47 & 52 & 0.87 \\
\hline $\mathrm{SE}$ & 0.1440 & .050 & $0.10 \times]$ \\
\hline \multicolumn{4}{|c|}{ Cowpea Cultivars } \\
\hline Tvx $46.59 .(1) 3 \mathrm{E}$ & 0.25 & .30 & 0.30 \\
\hline TNK8-6.3 & 0.22 & .15 & $0.31)$ \\
\hline Tera Local & 0.42 & .33 & 0.77 \\
\hline Sadore L_ocal & (1.8. 8.3 & .23 & $0, \%$ \\
\hline Dan Illa & 0.27 & 1).2K & $0.3 x$ \\
\hline TN5-78 & 0.52 & 0.55 & 0.36 \\
\hline SE & 0.0137 & 0.156 & 0.086 \\
\hline
\end{tabular}

\section{Discussion}

Interaction between cultivars and $P$ rates was observed with some cultivars declining in yield at higher $P$ rates. This decline may have been due to millet competition. Better growth of the pear! millet (the dominant component) could have suppressed the cowpea. Some cultivars did not respond to $\mathrm{P}$ rate. $\mathrm{A}$ similar phenomenon was observed where fertilizer application significantly increased millet yields but had no effect on associated cowpea dry fodder [4]. Sadore Local. 